\title{
KNOWLEDGE, FAMILY AND SOCIAL SUPPORT, SELF EFFICACY AND SELF-CARE BEHAVIOUR IN PULMONARY TUBERCULOSIS PATIENTS
}

\author{
Tintin Sukartini, Navisa Khoirunisa, Laily Hidayati
}

Faculty of Nursing Airlangga University, Mulyorejo Street 60115 Surabaya, Indonesia

\begin{abstract}
Tuberculosis is a disease that requires lengthy treatment. Knowledge of tuberculosis as well as family and social support are considered as important components of efficacy decisions. This study was conducted to analyse the relationship between knowledge, family and social support and self-efficacy and self-care behaviour in patients with pulmonary tuberculosis. The research used a cross sectional design. The population were 77 people and 65 respondents were obtained using a purposive sampling technique. Instruments used were knowledge, family support, social support, self-efficacy and self-care behaviour questionnaires. The data analysis method used was the Spearman rho test with a significance value of $\alpha \leq 0.05$. There were significant correlations between knowledge $(p=0.003)$ and family support $(p=0.000)$ and self-efficacy. There was no correlation between social support $(p=0.106)$ and self-efficacy. There was a correlation between knowledge $(p=0.048)$, family support $(p=0.036)$ and social support $(p=0.022)$ and self-care behaviour. There was a relationship between knowledge and family support and self-efficacy, whereas social support had no relationship with self-efficacy. There was a relationship between knowledge, family support and social support and self-care behaviour. Future researchers are expected to be able to design quasi experimental research to determine cultural differences (habits) in patients with pulmonary tuberculosis.
\end{abstract}

Keywords: Self-care behaviour, Self-efficacy, Tuberculosis

\section{ABSTRAK}

Tuberculosis adalah penyakit yang membutuhkan perawatan dalam jangka waktu yang lama. Pengetahuan tentang tuberculosis, dukungan keluarga dan dukungan sosial penting bagi keputusan efikasi. Penelitian ini dilakukan untuk menganalisis hubungan antara pengetahuan, dukungan keluarga dan dukungan sosial dengan self-efficacy dan self-care behaviour pada pasien dengan tuberculosis paru. Penelitian ini menggunakan desain cross sectional. Populasi dalam penelitian ini sebanyak 77 orang dan diperoleh 65 responden dengan teknik purposive sampling. Instrumen menggunakan kuesioner pengetahuan, dukungan keluarga, dukungan sosial, self-efficacy dan self-care behaviour. Analisis data menggunakan uji Spearman's rho dengan nilai signifikansi $\alpha \leq 0.05$. Ada hubungan yang signifikan antara pengetahuan $(p=0,003)$ dan dukungan keluarga $(p=0,000)$ dengan self-efficacy. Tidak ada korelasi antara dukungan sosial $(p=0,106)$ dengan self-efficacy. Ada hubungan antara pengetahuan $(p=0,048)$ dukungan keluarga $(p=0,036)$ dan dukungan sosial $(p=0,022)$ dengan self-care behaviour. Ada hubungan antara pengetahuan dan dukungan keluarga dengan self-efficacy, sedangkan dukungan sosial tidak memiliki hubungan. Ada hubungan antara pengetahuan, dukungan keluarga dan dukungan sosial dengan self-care behaviour. Peneliti selanjutnya diharapkan dapat merancang penelitian quasi-experiment untuk menentukan perbedaan budaya (kebiasaan) pada pasien dengan TUBERCULOSIS paru.

Kata kunci: Perilaku perawatan diri, Efikasi diri, Tuberkulosis 


\section{BACKGROUND}

Pulmonary tuberculosis is still a major health problem in the community. Based on an Indonesian survey, Indonesia ranked second in the highest incidence of Tuberculosis in the world after India. This disease causes pain and suffering for around 10 million people every year and is one of the top ten causes of death worldwide (World Health Organization, 2017).

The prevalence of Pulmonary tuberculosis in Indonesia according to Riset Kesehatan Dasar (RISKESDAS) in 2013 was $0.4 \%$ of all the population who had been diagnosed with pulmonary tuberculosis, however, only $44.4 \%$ had been covered by the program (Badan Penelitian dan Pengembangan Kesehatan, 2013). Tuberculosis prevention programs are carried out, which include health promotion, prevention and early detection for patients with pulmonary tuberculosis that actively involve the community as well as providing the medication needed for recovery ( $\mathrm{Li}$ et al., 2017; Mhimbira, Cuevas, Dacombe, Mkopi, \& Sinclair, 2017). The number of new cases discovered by positive smear results were as many as 23,183 sufferers or a Case Detection Rate (CDR) of $56 \%$ (Badan Penelitian dan Pengembangan Kesehatan, 2013). In 2016 the number of new cases of pulmonary tuberculosis in Surabaya was 2,382 patients. Positive smear recovery rate is $74.12 \%$. When compared with the previous year it showed an increase in treatment success rate of $4.15 \%$ in Surabaya (Dinas Kesehatan Kota Surabaya, 2016).

Tuberculosis is a disease that requires lengthy treatment and may lead the sufferers to decrease in selfconfidence (self-efficacy) and need a good level of self-care behaviour in order to achieve maximum healing (Ambaw, Mayston, Hanlon, \& Alem, 2015; Connolly, Edelstein, \& Ramakrishnan, 2007; Eyanoer, 2018). Knowledge of tuberculosis is considered as an important factor in the process of healing the disease (Mustaq et al., 2010). By having knowledge, it is expected that patients can overcome problems related to their disease and also so that they can anticipate using preventive measures as well as healing processes for tuberculosis (Biya et al., 2014). In addition, it is expected that they have high selfconfidence or self-efficacy to take action in managing chronic diseases so that they can carry out self-care for better health outcomes (Ludman et al., 2013).

Family support is one of the factors that can affect self-efficacy and self-care behaviour in patients with pulmonary tuberculosis (Hasanah, Makhfudli, \& Wahyudi, 2018; Muhtar, 2013). Family support can lead to feelings of calmness and positive attitudes, especially the support obtained from the closest family member, which can lead to feelings of inner peace within a person. Receiving the necessary attention from family members as well as being helped in their daily routine, given financial assistance, receiving emotional and moral support and motivation for early recovery are all considered to be examples of good family support and care (KaulagekarNagarkar, Dhake, \& Jha, 2012).

Social support is one of the key ways to influence health-improvement behaviour, medication adherence and improved health outcomes (Shin et al., 2008). The role of social support is considered important as a mechanism to manage life stressors and improve health and well-being (Dollete et al., 2004). Social support is a form of support from others that shows that someone is cared for, valued, respected and involved in the community. Social support can be obtained from peers and health workers. With the existence of good social support, it is hoped that it can improve self-efficacy and support good self-care behaviour in tuberculosis patients.

This study was conducted to analyse the relationship between patient's knowledge, family support and social support and self-efficacy and self-care behaviour in patients with pulmonary tuberculosis.

\section{METHODS}

This research was quantitative research using a cross sectional research 
design. The population in this study were all patients with pulmonary tuberculosis. The sample size was 65 respondents. The sampling technique in this study used a non probability sampling technique with a purposive sampling approach. The study was conducted over 3 months, from June until August 2018. Inclusion criteria were: all patients with pulmonary tuberculosis who were being actively treated and in the intensive phase and continuation phase, respondents could read and write and were willing to participate as research respondents. Exclusion criteria in this study were respondents who could not read and write, respondents aged under five and respondents with communication disorders. The criteria for drop out in this study were respondents who did not complete the questionnaire.

There were five questionnaires used in this study, namely knowledge, family support, social support, self-efficacy and self-care behaviour questionnaires. The knowledge questionnaire was adapted from a questionnaire used by Pratiwi (2010) that had been tested for validity and reliability with Cronbach Alpha 0.782 . This questionnaire consisted of 10 questions with the correct answer score getting the value 1 and the incorrect answer score getting the value 0 . The level considered to be good knowledge were results between $76-100 \%$, the level of knowledge was sufficient if the results were between $56-75 \%$ and the level of knowledge was insufficient if the results were $<56 \%$.

The family support questionnaire was adapted from a questionnaire by Kurniawan (2016) that had been tested for validity and reliability with Cronbach Alpha 0.950 . The family support questionnaire consisted of 12 items of questions which included 3 dimensions namely emotional support, instrumental support and informational support with the following score: $\quad$ Never $=0$; $\quad$ Sometimes $=1$; Frequently=2; Always $=3$. The measurement results were categorized as insufficient, sufficient and good.

The social support questionnaire was adapted from a questionnaire from Juliandari (2014) that had been tested for validity and reliability with Cronbach Alpha 0.742. Refer to the pre-existing questionnaire based on the following parameters: appraisal support, tangible support, informational support and emotional support. There were 12 positive questions and 8 negative statements. Respondents can choose favorable question, the very inappropriate answer $=0$, did not match $=1$, sometimes accordingly=2, $\quad$ matched $=3$, very suitable $=4$, while for unfavorable the answer was very inappropriate $=4$, incompatible $=3$, sometimes appropriate $=2$, according $=1$, very suitable $=0$.

The self-efficacy questionnaire by Muhtar (2013) had been tested for validity and reliability with Cronbach Alpha 0.822 . This questionnaire covered three dimensions of self-efficacy, namely magnitude, structure and generality consisting of 27 items with a 1-5 Likert scale, with the following assessment conditions: positive questions: Unsure $=1$; Unsure=2; Sure enough=3; Sure $=4$; Very confident $=5$. And for the negative questions: Unsure $=5$; Unsure $=4$; Sure enough $=3$; Sure $=2$; Very confident $=1$. There was a score range of between 27 135.

The self-care behaviour questionnaire was adapted from Muhtar's (2013) questionnaire that was tested for validity and reliability with Cronbach Alpha 0.714 . This questionnaire covered three dimensions of self-care namely self-care demand, self-care agency and self-care capacity which contained questions about self-care behaviour, namely: conducting a health check, implementing a treatment program and taking measures to prevent disease transmission. It consisted of 25 question items using a Likert scale of 1-5. For positive statements; never $=1$; rarely $=2$; sometimes $=3$; often $=4$; very often $=5$. And for negative questions; never $=5$; rarely $=4$; sometimes $=3$; often $=2$; very often $=1$ and there were a range of scores between 25 and 125 .

Researchers

distributed questionnaires to the respondents who were willing to participate in order to get the data needed. In this study, researchers were assisted by research assistants from 
fellow pulmonary TUBERCULOSIS researchers. In filling out the questionnaire, researchers had the duty to assist and encourage respondents to fill in all the questions in the questionnaire and after completing all the questionnaires, the respondents returned the questionnaire to the researcher. Data collected was recapitulated and data analysis was performed by researchers using SPSS 23 statistical software.

Statistical analysis consisted of two stages, which were descriptive and inferential analysis. Descriptive analysis included the mean, median, and standard deviation. Inferential analysis used the Spearman's rho test statistics to determine the relationship between the independent and dependent variables. Confidence interval was $95 \%$ with alpha $(\alpha)=0.05$ if the results of the statistical test ( $p$-value) are less than or equal to $\alpha=0.05$. The strength of the relationship is expressed as ( $r$ ) $0.90-1.0=$ very strong correlation, 0.70-0.89=strong correlation, 0.40 $0.69=$ moderate correlation, 0.10 $0.39=$ weak correlation, and 0.00 $0.10=$ negligible correlation (Schober \& Schwarte, 2018).

The research was clarified by ethical number 981-KEPK 2018 from Faculty of Nursing, Universitas Airlangga.

RESULTS

Table 1. Demographic characteristics of respondents

\begin{tabular}{lll}
\hline Characteristics & $\mathbf{n}$ & $\%$ \\
\hline Gender & & \\
Male & 27 & 41.5 \\
Female & 38 & 58.5 \\
\hline
\end{tabular}

\begin{tabular}{lll}
\hline Characteristics & $\mathbf{n}$ & $\%$ \\
\hline Total & 65 & 100 \\
\hline Age & & \\
17-25 years & 11 & 16.9 \\
26-35 years & 15 & 23.1 \\
36-45 years & 10 & 15.4 \\
46-59 years & 21 & 32.3 \\
$\quad 60-74$ years & 8 & 12.3 \\
\hline Total & 65 & 100 \\
\hline Education Level & & \\
$\quad$ University & 2 & 3.1 \\
$\quad$ Senior High School & 19 & 29.2 \\
$\quad$ Primary Education & 44 & 67.7 \\
\hline Total & 65 & 100 \\
\hline Work & & \\
$\quad$ Working & 36 & 55.4 \\
$\quad$ Not working & 29 & 44.6 \\
\hline Total & 65 & 100 \\
\hline Smoking history & & \\
$\quad$ Smoked & 20 & 30.8 \\
$\quad$ Not smoked & 45 & 69.2 \\
\hline Total & 65 & 100 \\
\hline Medication phase & & \\
$\quad$ Intensive & 26 & 40 \\
$\quad$ Continuous & 39 & 60 \\
\hline Total & 65 & 100 \\
\hline$\quad$ & \\
\hline
\end{tabular}

The table shows that the majority of respondents were women, which was as many as 38 people $(58.5 \%)$ with the majority of the age range being 46-59 years, which was as many as 21 people $(32.3 \%)$. The majority of respondents had a primary education level, which was 44 people $(67.7 \%)$ and were working, which was as many as 36 people (55.4\%). The majority didn't smoke, which was as many as 45 people $(69.2 \%)$ and were in the advanced treatment stage, which was as many as 39 people (60\%).

Table 2. Cross tabulation between knowledge, family support, social support and self-efficacy and self-efficacy in pulmonary tuberculosis patients

\begin{tabular}{|c|c|c|c|c|c|c|c|c|}
\hline \multirow{3}{*}{ Variables } & \multicolumn{4}{|c|}{ Self-efficacy } & \multirow{2}{*}{\multicolumn{2}{|c|}{ Total }} & \multirow{3}{*}{$p$} & \multirow{3}{*}{$(r)$} \\
\hline & \multicolumn{2}{|c|}{ Enough } & \multicolumn{2}{|c|}{ Good } & & & & \\
\hline & $n$ & $\%$ & $\mathrm{n}$ & $\%$ & $\mathrm{n}$ & $\%$ & & \\
\hline \multicolumn{9}{|l|}{ Knowledge } \\
\hline Poor & 3 & 4.62 & 0 & 0 & 3 & 4.62 & \multirow{4}{*}{0,003} & \multirow{4}{*}{0,365} \\
\hline Sufficient & 9 & 13.85 & 5 & 7.69 & 14 & 21.54 & & \\
\hline Good & 15 & 23.08 & 33 & 50.77 & 48 & 73.85 & & \\
\hline Total & 27 & 41.54 & 38 & 58.46 & 65 & 100 & & \\
\hline \multicolumn{9}{|l|}{ Family support } \\
\hline Sufficient & 18 & 27.69 & 6 & 9.23 & 24 & 36.92 & \multirow{3}{*}{0,000} & \multirow{3}{*}{0,520} \\
\hline Good & 9 & 13.85 & 32 & 49.23 & 41 & 63.08 & & \\
\hline Total & 27 & 41.54 & 38 & 58.46 & 65 & 100 & & \\
\hline Social Support & & & & & & & 0,106 & 0,202 \\
\hline
\end{tabular}


Jurnal Keperawatan Soedirman 14 (2) 2019 : 114 - 125

\begin{tabular}{lllllll}
\hline \hline Poor & 7 & 10.77 & 4 & 6.15 & 11 & 16.92 \\
Sufficient & 20 & 30.77 & 34 & 52.31 & 54 & 83.08 \\
\hline Total & 27 & 41.54 & 38 & 58.46 & 65 & 100 \\
\hline
\end{tabular}

Table 2 reports the results of patient's knowledge with spearman's rho correlation statistical test that showed that $p$-value is 0.003 with a correlation coefficient value of $(r) 0.365$. That means that the better the level of knowledge, the better the level of self-efficacy for patients with pulmonary tuberculosis. The $p$-value that resulted from family support with Spearman's rho correlation statistical test was 0.000 which means that there is a relationship between family support and self-efficacy. The correlation coefficient value $(r)$ was 0.520 and was interpreted as a moderate relationship level.

The better the family support, the better the self-efficacy of patients with pulmonary tuberculosis. The results of social support with spearman's rho correlation statistical test showed that the $\mathrm{p}$-value was 0.106 which means that there was no relationship between social support and self-efficacy in patients with pulmonary tuberculosis.

Table 3. Crosstabulation between knowledge, family support, social support and self-efficacy and self-care behaviour in pulmonary tuberculosis patients

\begin{tabular}{|c|c|c|c|c|c|c|c|c|}
\hline \multirow{3}{*}{ Variables } & \multicolumn{4}{|c|}{ Self-care behaviour } & \multirow{2}{*}{\multicolumn{2}{|c|}{ Total }} & \multirow{3}{*}{$\mathbf{p}$} & \multirow{3}{*}{ (r) } \\
\hline & \multicolumn{2}{|c|}{ Enough } & \multicolumn{2}{|c|}{ Good } & & & & \\
\hline & $\mathbf{n}$ & $\%$ & $\mathbf{n}$ & $\%$ & $\mathbf{n}$ & $\%$ & & \\
\hline Knowledge & 2 & & 1 & & & & \multirow{5}{*}{0,048} & \multirow{5}{*}{0,246} \\
\hline Poor & 7 & 3.08 & 7 & 1.54 & 3 & 4.62 & & \\
\hline Sufficient & 13 & 10.77 & 35 & 10.77 & 14 & 21.54 & & \\
\hline Good & & & & 53.85 & 48 & 73.85 & & \\
\hline Total & 27 & 41.54 & 38 & 58.46 & 65 & 100 & & \\
\hline \multicolumn{9}{|l|}{ Family support } \\
\hline Sufficient & 12 & 18.46 & 12 & 18.46 & 24 & 36.92 & \multirow{3}{*}{0,036} & \multirow{3}{*}{0,261} \\
\hline Good & 10 & 15.38 & 31 & 47.69 & 41 & 63.08 & & \\
\hline Total & 27 & 41.54 & 38 & 58.46 & 65 & 100 & & \\
\hline \multicolumn{9}{|l|}{ Social Support } \\
\hline Poor & 7 & 10.77 & 4 & 6.15 & 11 & 16.92 & \multirow{3}{*}{0,022} & \multirow{3}{*}{0,284} \\
\hline Sufficient & 15 & 23.08 & 39 & 60 & 54 & 83.08 & & \\
\hline Total & 27 & 41.54 & 38 & 58.46 & 65 & 100 & & \\
\hline
\end{tabular}

The result of knowledge with Spearman's rho statistical test showed that the $p$ value was 0.048 which means that there is a relationship between knowledge and self-care behaviour with the correlation value $(r)$ of 0.246 and it is interpreted as a weak level of relationship. A higher knowledge level usually means better self-care behaviour in patients with pulmonary tuberculosis. The result of family support with Spearman's rho correlation statistical test showed that the $p$ value is 0.036 , which means that there was a meaningful relationship between family support and self-care behaviour with the correlation value $(r)$ of 0.261 and it is interpreted as a weak level of relationship. A higher level of family support tends to mean better self-care behaviour in patients with pulmonary tuberculosis. The results of social support with Spearman's rho correlation statistical test showed that the $p$ value was 0.022 , which means that there was a meaningful relationship between social support and self-care behaviour with the correlation value (r) of 0.284 and it is interpreted as a weak level of relationship. The higher the social support, the better the self-care behaviour of patients with pulmonary tuberculosis is.

\section{DISCUSSION}

This study found that there was a positive relationship between knowledge and self-efficacy in patients with pulmonary tuberculosis. The results of this study were consistent with previous research which states that there is a positive and significant relationship 
between knowledge and self-efficacy (Herawati, Purwanti, \& Teguh, 2016; Prayogi, 2017). Self-efficacy is a socialcognitive theory, which is defined as an individual's belief in his or her own ability to implement certain behaviours or a set of behaviours (Bandura, 1977). The impact of self-efficacy in supporting decisions is basically mediated by preparation rather than knowledge (Miller et al., 2013). Knowledge can be the basis for individuals to determine their attitudes and behaviour (Prayogi, 2017) and is considered as an important factor that can affect the health status of pulmonary tuberculosis patients during the treatment process (Rasooli, Ahmadnezhad, Jelyani, \& HolakouieNaieni, 2015). Mekonnen \& Azagew (2018) stated that there is a relationship between the knowledge level of tuberculosis patients and their adherence to treatment. This knowledge includes basic knowledge of the initial symptoms of tuberculosis, the process of transmission of pulmonary tuberculosis disease, knowledge of the type and duration of tuberculosis treatment, as well as knowledge of the existence of PMO (Drug Control Supervisor). Insufficient knowledge of tuberculosis is associated with low compliance (Tachfouti, Slama, Berraho, \& Nejjari, 2012).

Based on the description above it can be concluded that knowledge has a relationship with self-efficacy. Self-efficacy can motivate behaviour regarding health promotion, both directly and indirectly. Good knowledge results in good selfefficacy.

Family support was found to have a relationship with self-efficacy. The results of this study are in line with the research of Kaşikçi \& Alberto (2007) which stated that there was a positive relationship between family support and self-efficacy. Family plays an important role in providing support to tuberculosis clients during treatment (Irawan, Rahayuwati, \& Yani, 2017). Rozi et al., (2017) stated that there was a relationship between family support and coping mechanisms for tuberculosis patients. Family support is usually defined as client's relationships with their families
(Friedman, 2010). One function of the family is to provide healthcare to the family therefore the family will provide care to family members who suffer from tuberculosis. There are families that perform their functions well, which suggests that families can adapt to patient diseases and role changes and this is effective in reducing the risk of depression in patients. In contrast, family dysfunction can result in a home environment that may cause stress to patients with tuberculosis (Qiu et al., 2018). Positive reinforcement from spouses and families may be considered as having strong family support.

According to Muhtar (2013), good self-efficacy results from family support. Increased knowledge and positive actions of family members can improve the family's role in providing support to sick family members (Li et al., 2018). The results of research conducted by Rachmawati, Suryani, \& Isabella (2015) showed that the efforts to improve the fulfilment of family's psychosocial needs were increasing the frequency of care, developing methods of care and providing information, strengthening knowledge about the information provided and improving the ease of consultation with the patient by using counselling techniques.

Based on the description above it can be concluded that family support has a relationship with self-efficacy. Effective family functioning can be interpreted as family members having a sense of belonging in the family, and maintaining their personality in a way that meets the psychological needs of family members. Family support allows families to function properly, improves adaptation skills and can improve the health of family members. Individuals who have good family support will become more optimistic and confident that they can improve their self-efficacy.

This study showed that there is no relationship between social support and self-efficacy. Some studies revealed that perceived social support has an effect on self-efficacy (Wang, Qu, \& Xu, 2016; Wu, Lee, Chou, Chen, \& Huang, 2018), but the results of this study showed there was no significant effect. This may have occurred 
because of the differences in study population, instruments used for data collection and analytical methods. According to Bandura (1997) the source of behaviour control is environmental, behavioural and personal; each person has different self-efficacy level depending on the presence of others as well as their physiological and emotional states. According to Feist \& Fiest (2008), the level of self efficacy is affected by responsive or unresponsive social environments.

In this case one of the factors that influences and can hinder the provision of social support are the dimensions of selfesteem support or feedback. Feedback from the environment may be the most important factor that can influence the level of social support. In this study there were still many individuals who received less social support from the community because there is still a bad social stigma around people with pulmonary tuberculosis. Patients feel embarrassed and afraid to be excluded when they gather with the community because they suffer from pulmonary tuberculosis disease. This can cause an individual to withdraw or avoid others. This experience is a factor that can reduce their selfconfidence because individuals are not able to control changes in their environment. Social support is not related to self-efficacy which is allegedly due to various social circumstances and conditions with different self-beliefs.

This study showed that there is a relationship between knowledge and selfcare behaviour. This result is consistent with Bibbins-Domingo et al., (2011) who viewed that knowledge has a relationship with self-care behaviour. According to AlizadehSeiouki et all., (2015), self-care behaviour can be promoted by increasing knowledge. Knowledge is the dominant factor in the formation of one's attitude; people with greater knowledge have more concerned attitudes and consequently engage more in effective protective behaviours (De Pretto, Acreman, Ashfold, Mohankumar, \& Campos-Arceiz et al., 2015). Knowledge is a necessary and essential basis for developing self-care (Artinian et al., 2002; Taulbee, 2009).
Taylor \& Renpenning (2011) defined selfcare as the activities that a person initiates and performs in order to maintain their life, healthy functioning, continuing personal development and wellbeing (Taylor \& Renpenning, 2011). People with greater knowledge are more concerned about selfcare and consequently engage more in effective protective behaviours (De Pretto et al., 2015).

Based on the description above, it can be concluded that knowledge has a relationship with self-care behaviour. Knowledge is an influential factor for daily care, because with good levels of knowledge the patient will understand his physical condition and will be expected to be able to demonstrate good self-care behaviour to maintain his health. The existence of good knowledge levels of patients may improve their life styles in a beneficial way so that they become cured of tuberculosis. With the support methods in place such as providing information about the disease, sputum management, environmental management and prevention of food transmission the patient can make the right decision for his treatment.

Another finding from this study was the relationship between family support and self-care behaviour. The results of this study are in accordance with Muhtar (2013), which stated that the role of the family in maintaining health is demonstrated by their continuous support to the tuberculosis patients in terms of reminding them to take their medication and helping usher them into a routine for picking up the tuberculosis drugs. Family is the most important source of social support that can reduce or improve family's health status, well-being and self-care activities (Shahriari, Alimohammadi, \& Ahmadi, 2016; Thomas, Liu, \& Umberson, 2017). Family attitudes can affect patients with pulmonary tuberculosis and can influence their behaviour including self-care behaviour (Rachmawati et al., 2015). Individuals who have good family support have good levels of self-care behaviour (Shahriari et al., 2016). Samal (2017) mentioned that family members play a great role in tuberculosis 
control as supporters and care-givers to the tuberculosis patient, especially support in terms of care and taking medication regularly as well as nutritional and livelihood support.

Based on the description above, it can be concluded that family support has a relationship with self-care behaviour. With good family involvement, especially in the instrumental dimension by providing direct aid and tangible support, families can help to meet the needs of the sick family members so they become healthy and free from tuberculosis.

This study also found a relationship between social support and self-care behaviour. The results of this study indicate that there is a statistically significant relationship between social support and self-care in tuberculosis patients. This is consistent with the study of Mohebi et al., (2018) which stated that social support, as an important psychosocial concept, can have a beneficial effect on self-care behaviour. The ability to self-care for tuberculosis sufferers is influenced by positive supporting elements of the social environment (the closest people to the patient) including family members, neighbours, friends or colleagues ( $\mathrm{He}$ et al., 2016; Saifullah, Mulyadi, \& Asniar, 2018).

Basically social support is a functional content of relationships that can be categorized into four types of behaviour or actions that support the patient in the form of emotional support, instrumental support (involving direct aid and tangible support), information support, and assessment support that is useful for self evaluation (Glanz, Rimer, \& Viswanath, 2008). The source of social support that has the most influential role in self-care behaviour is tangible support in the form of support from peers such as getting help from others. Families only play a role in controlling bad behaviour. Patients who have good social support usually have good self-care behaviour. The function of social support for patients is to provide a sense of security and to increase their motivation and confidence so that patients will lead a healthy lifestyle.

\section{CONCLUSION AND RECOMMENDA TION}

There was a relationship between knowledge and family support with selfefficacy, while social support had no relationship with self-efficacy. There was a relationship between knowledge, family support and social support with self-care behaviour in patients with pulmonary tuberculosis. Future researchers are expected to be able to design quasiexperimental research to determine cultural differences (habits) in patients with pulmonary tuberculosis.

\section{REFERENCES}

AlizadehSeiouki, H., SharifiRad, J., Jadgal, K., Zareban, I., \& NakhaeiMoghadam, T. (2015). Impact of Educational Intervention on Patients Behaviour with Smearpositive Pulmonary Tuberculosis: A Study Using the Health Belief Model. Materia Socio Medica, 27(4), 229. https://doi.org/10.5455/msm.2015.27 .229-233

Ambaw, F., Mayston, R., Hanlon, C., \& Alem, A. (2015). Depression among patients with tuberculosis: Determinants, course and impact on pathways to care and treatment outcomes in a primary care setting in southern Ethiopia - A study protocol. BMJ Open, 5(7), 1-10. https://doi.org/10.1136/bmjopen2015-007653

Artinian, N. T., Magnan, M., Christian, W., \& Lange, M. P. (2002). What Do Patients Know about Their Heart Failure? Applied Nursing Research, 15(4), 200-208. https://doi.org/10. 1053/apnr. 2002.35959

Badan Penelitian dan Pengembangan Kesehatan. (2013). Riset Kesehatan Dasar (RISKESDAS) 2013. Laporan Nasional 2013, 1-384. https://doi. org/ 1 Desember 2013

Bandura, A. (1977). Self-efficacy: toward a unifying theory of behavioural change. Psychological Review, 84(2), 191-215. 
Bandura, A. (1997). Self Efficacy: The Exercise of Control. New York: W.H.Freeman.

Bibbins-Domingo, K., Broucksou, K. A., Weinberger, M., Schillinger, D., Erman, B., Pignone, M., Baker, D. W. (2011). Relationship Between Literacy, Knowledge, Self-Care Behaviours, and Heart FailureRelated Quality of Life Among Patients With Heart Failure. Journal of General Internal Medicine, 26(9), 979-986. https://doi.org/10.1007/s 11606-011-1668-y

Biya, O., Gidado, S., Abraham, A., Waziri, N., Nguku, P., Nsubuga, P., Sabitu, K. (2014). Knowledge, care-seeking behaviour, and factors associated with patient delay among newlydiagnosed pulmonary tuberculosis patients, Federal Capital Territory, Nigeria, 2010 \& quot; Building a public health workforce in Nigeria through experiential training \&quot; Supplement sponsored by Nigeria Field Epidemiology and Laboratory Program. Pan African Medical Journal. Oladayo Biya et Al, 186(1), 1-5. https://doi.org/10.11694/pamj. supp.2014.18.1.4166

Connolly, L. E., Edelstein, P. H., \& Ramakrishnan, L. (2007). Why Is Long-Term Therapy Required to Cure Tuberculosis? PLoS Medicine, 4(3), e120. https://doi.org/10.1371/ journal.pmed.0040120

De Pretto, L., Acreman, S., Ashfold, M. J., Mohankumar, S. K., \& CamposArceiz, A. (2015). The Link between Knowledge, Attitudes and Practices in Relation to Atmospheric Haze Pollution in Peninsular Malaysia. PLoS ONE, 10(12), 1-18. https://doi.org/10.1371/journal.pone. 0143655

Dinas Kesehatan Kota Surabaya. (2016). Profil Kesehatan. Profil Kesehatan Surabaya, 53 hal.
Dollete, M., Steese, S., Phillips, W., Matthews, G., Hossfeld, B., \& Taormina, G. (2004). Understanding Girls' Circle As An Intervention on Perceived Social Support, Body Image, Self-Efficacy, Locus of Control and Self-Esteem. The Journal of Psychology, 90(2), 204215.

Eyanoer, P. C. (2018). Social acceptance among tuberculosis patients at Puskesmas Amplas Medan, Indonesia. IOP Conference Series: Earth and Environmental Science, 125(1). https://doi.org/10.1088/17551315/125/1/012101

Feist, J., \& Fiest, G. (2008). Theories of Personality. New York: McGraw-Hill Companies, Inc.

Friedman, M. (2010). Buku Ajar Keperawatan keluarga : Riset, Teori, dan Praktek (5th ed.). Jakarta: EGC.

Glanz, K., Rimer, B. K., \& Viswanath, K. (2008). Health Behaviour And Health Education: Theory, Research, and Practice. Health Behaviour and Health Education. Theory, Research, and Practice (4th ed.). San Francisco: John Wiley \& Sons. https://doi.org/10.1016/S00333506(49)81524-1

Hasanah, M., Makhfudli, \& Wahyudi, A. S. (2018). Hubungan Dukungan Keluarga Dengan Efikasi Diri Penderita Tuberculosis Multidrug Resistant (Tuberculosis-Mdr) Di Poli Tuberculosis-Mdr Rsud Ibnu Sina Gresik. Jurnal Kesehatan, 11(2), 72. https://doi.org/10.24252/kesehatan.v $11 \mathrm{i} 2.5415$

He, T., Chen, B., Yeh, H.-C., Peng, Y., Wang, X., Chai, C., Zhou, L. (2016). Social support received by multidrug-resistant tuberculosis patients and related factors: a crosssectional study in Zhejiang Province, People's Republic of China. Patient Preference and Adherence, 1063. https://doi.org/10.2147/ppa.s105655 
Herawati, E., Purwanti, O. S., \& Teguh, S. (2016). Hubungan Antara Pengetahuan Dengan Efikasi Diri Penderita Tuberkulosis Paru Di Balai Besar Kesehatan Paru Masyarakat Surakarta. Universitas Muhamma diyah Surakarta.

Irawan, A., Rahayuwati, L., \& Yani, D. I. (2017). Analysis of The Factors That Have An Influence on Tuberculosis (Tuberculosis) Patient's Self Efficacy and Medical Behaviour in Garut Regency. Advances in Health Science Research, 6, 625-632.

Juliandari, N. M. (2014). Hubungan Antara Dukungan Sosial dan Coping Stres Dengan Kualitas Hidup Pasien TUBERCULOSIS Paru di Puskesmas Perak Timur Surabaya Tahun 2014. Universitas Airlangga.

Kaşikçi, M. K., \& Alberto, J. (2007). Family support, perceived self-efficacy and self-care behaviour of Turkish patients with chronic obstructive pulmonary disease. Journal of Clinical Nursing, 16(8), 1468-1478. https://doi.org/10.1111/j.13652702.2006.01782.x

Kaulagekar-Nagarkar, A., Dhake, D., \& Jha, P. (2012). Perspective of tuberculosis patients on family support and care in rural Maharashtra. The Indian Journal of Tuberculosis, 59(4), 224-230.

Kurniawan, N. (2016). Hubungan Antara Dukungan Keluarga Dengan Tingkat Kepatuhan Klien Tuberkulosis Paru Dalam Menjalani Pengobatan di Puskesmas Pegirian Surabaya. Universitas Airlangga.

Li, J., Chung, P. H., Leung, C. L. K., Nishikiori, N., Chan, E. Y. Y., \& Yeoh, E. K. (2017). The strategic framework of tuberculosis control and prevention in the elderly: A scoping review towards End TUBERCULOSIS targets. Infectious Diseases of Poverty, 6(1), 1-12. https://doi.org/10.1186/s40249-0170284-4

Li, X., Wang, B., Tan, D., Li, M., Zhang, D., Tang, C., Xu, Y. (2018). Effectiveness of comprehensive social support interventions among elderly patients with tuberculosis in communities in China: a communitybased trial. Journal of Epidemiology and Community Health, 72(5), 369375. https://doi.org/10.1136/jech2017-209458

Ludman, E. J., Peterson, D., Katon, W. J., Lin, E. H. B., Von Korff, M., Ciechanowski, P., ... Gensichen, J. (2013). Improving confidence for self care in patients with depression and chronic illnesses. Behavioural Medicine (Washington, D.C.), 39(1), 1-6. https://doi.org/10.1080/0896 4289.2012.708682

Mekonnen, H. S., \& Azagew, A. W. (2018). Non-adherence to anti-tuberculosis treatment, reasons and associated factors among TUBERCULOSIS patients attending at Gondar town health centers, Northwest Ethiopia. BMC Research Notes, 11(1), 1-8. https://doi.org/10.1186/s13104-0183789-4

Mhimbira, F. A., Cuevas, L. E., Dacombe, R., Mkopi, A., \& Sinclair, D. (2017). Interventions to increase tuberculosis case detection at primary healthcare or community level services. Cochrane Database of Systematic Reviews, (11). https://doi.org/10.1002/14651858.CD 011432

Miller, S. M., Hudson, S. V., Egleston, B. L., Manne, S., Buzaglo, J. S., Devarajan, K.,... Meropol, N. J. (2013). The relationships among knowledge, self-efficacy, preparedness, decisional conflict, and decisions to participate in a cancer clinical trial. PsychoOncology, 22(3), 481-489. https://doi.org/10.1002/pon.3043 
Mohebi, S., Parham, M., Sharifirad, G., Gharlipour, Z., Mohammadbeigi, A., \& Rajati, F. (2018). Relationship between perceived social support and self-care behaviour in type 2 diabetics: A cross-sectional study. Journal of Education and Health Promotion, 7, 48. https://doi.org/10. 4103/jehp.jehp_73_17

Muhtar. (2013). Pemberdayaan Keluarga Dalam Peningkatan Self Efficacy dan Self Care Activity Keluarga dan Penderita TUBERCULOSIS Paru. Jurnal Ners, 8(Oktober), 229-239.

Mustaq, M. U., Majrooh, M. A., Ahmad, W., Rzwan, M., Luqman, M. Q., Aslam, M. J., Shad, M. A. (2010). Knowledge, attitudes and practices regarding tuberculosis in two districts of Punjabi, Pakistan. International Journal of Tuberculosis and Lung Disease, 14(3), 303-310.

Pratiwi, T. (2010). Hubungan Pengetahuan Pasien Tuberkulosis Paru Dengan Kepatuhan Pelaksanaan Program DOTS di Puskesmas Pegirian Surabaya. Universitas Airlangga.

Prayogi, B. (2017). The Correlation of Knowledge and Self-Efficacy in Preventing The Spread of Pulmonary Tuberculosis. Jurnal Ners Dan Kebidanan, 4(3), 235-238. https://doi.org/10.26699/jnk.v4i3.AR T.p235-238

Qiu, L., Yang, Q., Tong, Y., Lu, Z., Gong, Y., \& Yin, X. (2018). The Mediating Effects of Stigma on Depressive Symptoms in Patients With Tuberculosis: A Structural Equation Modeling Approach. Frontiers in Psychiatry, 9(November), 1-9. https://doi.org/10.3389/fpsyt.2018.00 618

Rachmawati, N. I., Suryani, \& Isabella, C. (2015). Kebutuhan Psikososial Keluarga yang Mempunyai Anggota Keluarga Menderita Tuberculosis Paru. Jurnal Keperawatan
Padjadjaran, 3(1), 25-32.

https://doi.org/10.24198/jkp.v3n1.4

Rasooli, A., Ahmadnezhad, E., Jelyani, K. N., \& Holakouie-Naieni, K. (2015). Knowledge and Attitude toward Tuberculosis among Tuberculosis Patients Seeking Help in Diagnostic and Treatment Centers, Kabul Province in Afghanistan. Iran $\mathrm{J}$ Public Health, 44(5), 711-713. Retrieved from http://ijph.tums.ac.ir

Rozi, A. F., Sukartini, T., \& Makhfudli. (2017). Hubungan Dukungan Keluarga Dengan Mekanisme Koping Pasien Tuberkulosis Paru di Rumah Sakit Paru Jember Penelitian Cross Sectional. Universitas Airlangga.

Saifullah, Mulyadi, \& Asniar. (2018). Faktor-Faktor Yang Tuberkulosis Paru Berhubungan Dengan Perilaku Perawatan Kesehatan Factors Related to Health Care Behaviour of Lung Tuberculosis belum ada Negara yang terbebas dari Indonesia yang didiagnosis Tuberkulosis Paru provinsi dengan angka kejadi. Jurnal Ilmu Keperawatan, 6(1).

Samal, J. (2017). Family perspectives in the care and support of tuberculosis patients: An Indian context. The Journal of Association of Chest Physicians, 5(2), 67. https://doi.org/ 10.4103/2320-8775.202899

Schober, P., \& Schwarte, L. A. (2018). Correlation coefficients: Appropriate use and interpretation. Anesthesia and Analgesia, 126(5), 1763-1768. https://doi.org/10.1213/ANE.000000 0000002864

Shahriari, M., Alimohammadi, N., \& Ahmadi, M. (2016). Effects of a family centered program on perceived social support in patients with congestive heart failure: An interventional study. Journal of Education and Health Promotion, 
5(1), 6. https://doi.org/10.4103/22779531.184559

Shin, S., Munoz, M., Espiritu, B., Zeladita, J., Sanchez, E., Callacna, M., Sebastian, J. L. (2008). Psychosocial impact of poverty on antiretroviral nonadherence among HIV-TUBERCULOSIS coinfected patients in Lima, Peru. Journal of the International Association of Physicians in AIDS Care (Chicago, III. : 2002), 7(2), 74-81. https://doi. org/10.1177/1545109708315326

Tachfouti, N., Slama, K., Berraho, M., \& Nejjari, C. (2012). The impact of knowledge and attitudes on adherence to tuberculosis treatment: A case-control study in a Moroccan region. Pan African Medical Journal, 12(1), 1-8.

Taulbee, P. (2009). Heart Failure Knowledge and Performance of SelfCare Behaviours.

Taylor, S. G., \& Renpenning, K. (2011). Self-care science, nursing theory, and evidence-based practice. Choice Reviews Online (Vol. 49).
https://doi.org/10.5860/CHOICE.492104

Thomas, P. A., Liu, H., \& Umberson, D. (2017). Family Relationships and Well-Being. Innovation in Aging, 1(3), 1-11. https://doi.org/10.1093/ geroni/igx025

Wang, C.-M., Qu, H.-Y., \& Xu, H.-M. (2016). Relationship between social support and self-efficacy in women psychiatrists. Chinese Nursing Research, 2(4), 103-106. https://doi. org/10.1016/j.cnre.2015.10.002

World Health Organization. (2017). Global Tuberculosis Report 2017.

Wu, K. T., Lee, P. S., Chou, W. Y., Chen, S. H., \& Huang, Y. T. (2018). Relationship between the social support and self-efficacy for function ability in patients undergoing primary hip replacement. Journal of Orthopaedic Surgery and Research, 13(1), 1-8. https://doi.org/10.1186/ s13018-018-0857-3 